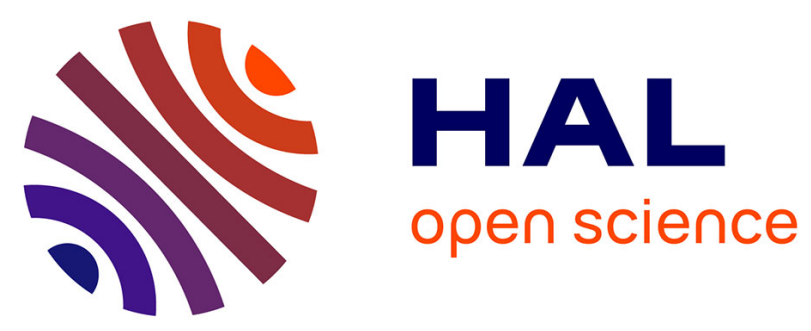

\title{
Mutation pattern of Lamivudine resistance in relation to Hepatitis B Genotypes Hepatitis B Genotypes differ in their Lamivudine resistance associated mutation pattern
}

Hans C. Damerow, Lilly Yuen, Johannes Wiegand, Christine Walker, C Thomas Bock, Steve Locarnini, Hans Tillman

\section{To cite this version:}

Hans C. Damerow, Lilly Yuen, Johannes Wiegand, Christine Walker, C Thomas Bock, et al.. Mutation pattern of Lamivudine resistance in relation to Hepatitis B Genotypes Hepatitis B Genotypes differ in their Lamivudine resistance associated mutation pattern. Journal of Medical Virology, 2010, 82 (11), pp.1850. 10.1002/jmv.21902 . hal-00613774

\section{HAL Id: hal-00613774 \\ https://hal.science/hal-00613774}

Submitted on 6 Aug 2011

HAL is a multi-disciplinary open access archive for the deposit and dissemination of scientific research documents, whether they are published or not. The documents may come from teaching and research institutions in France or abroad, or from public or private research centers.
L'archive ouverte pluridisciplinaire HAL, est destinée au dépôt et à la diffusion de documents scientifiques de niveau recherche, publiés ou non, émanant des établissements d'enseignement et de recherche français ou étrangers, des laboratoires publics ou privés. 


\section{Mutation pattern of Lamivudine resistance in relation to Hepatitis B Genotypes \\ Hepatitis B Genotypes differ in their Lamivudine resistance associated mutation pattern}

\begin{tabular}{|r|l|}
\hline Journal: & Journal of Medical Virology \\
\hline Manuscript ID: & JMV-10-1852.R1 \\
\hline Diley - Manuscript type: & Research Article \\
\hline Author: & $19-J u n-2010$ \\
\hline Complete List of Authors: & $\begin{array}{l}\text { Damerow, Hans; Universitätsklinikum Leipzig, Medizinische Klinik } \\
\text { und Poliklinik II } \\
\text { Yuen, Lilly; VIDRL, R\&MD } \\
\text { Wiegand, Johannes; Universitätsklinikum Leipzig, Medizinische } \\
\text { Klinik und Poliklinik II } \\
\text { Walker, Christine; University of Tübingen, Department of Molecular } \\
\text { Pathology } \\
\text { Bock, C; Robert Koch Institut, Molekulare Epidemiologie viraler } \\
\text { Erreger } \\
\text { Locarnini, Steve; VIDRL, R\&MD } \\
\text { Tillman, Hans; DCRI, GI }\end{array}$ \\
\hline Keywords: & Hepatitis B, Genotype, Lamivudine , resistance , mutation pattern \\
\hline
\end{tabular}

\section{S ScholarONE \\ Manuscript Central}




\section{Mutation Pattern of Lamivudine Resistance in Relation to Hepatitis B Genotypes \\ Hepatitis B Genotypes Differ in their Lamivudine Resistance Associated Mutation Pattern}

Hans Damerow ${ }^{1 *}$, Lilly Yuen ${ }^{2 *}$, Johannes Wiegand ${ }^{1}$, Christine Walker ${ }^{3}$, C.-Thomas Bock ${ }^{3,4} @$, Stephen Locarnini, ${ }^{2} @$, Hans L. Tillmann ${ }^{1,5} @$

* and @ these authors contributed equally.

${ }^{1}$ Department of Internal Medicine, Neurology and Dermatology, Clinic for Gastroenterology and Rheumatology, University of Leipzig, Leipzig, Germany

${ }^{2}$ Victorian Infectious Diseases Reference Laboratory, North Melbourne, Victoria, Australia

${ }^{3}$ Department of Molecular Pathology, Institute for Pathology, University of Tübingen, Tübingen, Germany

${ }^{4}$ Robert Koch-Institute, Berlin, Germany

${ }^{5}$ Duke Clinical Research Institute, Duke University, Durham, NC, USA

Address of Correspondence:

Hans L. Tillmann, MD

Assistant Professor

Duke Clinical Research Institute

2400 Pratt Street

Duke University Medical Center, Box 17969

Durham NC 27705

Phone: (919) 668-4620

Fax: (919) 668-7164

Email: hans.tillmann@duke.edu

Running title: HBV Genotype and Lamivudine Resistance Pattern 


\begin{abstract}
Little is known about differences between individual hepatitis B genotypes and mutation patterns associated with lamivudine resistance. This study analyses the lamivudine associated mutation pattern in relation to the four major HBV-genotypes $A$ to $D$.

The PubMed database was screened for keywords "HBV OR Hepatitis B", "YMDD" , "genotype", and "lamivudine"; all identified publications published till June 2009 were analysed for differences in mutation pattern. To confirm the literature based findings the databases of two reference laboratories in Tübingen, Germany and in Melbourne, Australia were analysed.

Twenty nine studies were identified reporting 827 patients with known hepatitis B genotype who underwent lamivudine treatment and developed resistance mutations. The literature data revealed that genotype A favors the rtM204V mutation unlike the other major genotypes $(p<0.001)$, which corresponds to a significant difference in the mutation pattern of genotypes endemic in Asian countries and those found in the rest of the world. These significant findings of the literature review could be reproduced in the analysis of the databases from Tübingen and Melbourne. Furthermore, the rtL180M mutation is significantly connected to the rtM204V mutation in genotypes $A, B$, and $C$, respectively.

It is concluded that there is proof that HBV-genotypes differ in their mutation pattern of lamivudine resistance. Future studies will need to evaluate whether this will translate into genotype specific differences in resistance emergence on either entecavir or telbivudine as these antivirals differ in their mutation profile, rtM204V for entecavir and rtM204l for telbivudine.
\end{abstract}

Key Words: HBV, hepatitis B, genotype, lamivudine, resistance, YMDD 


\section{Introduction:}

Lamivudine was the first approved oral antiviral for the treatment of chronic hepatitis B virus (HBV) infection and remains one of the most frequently used nucleoside analogues, mostly because it is cheaper, though it may not be the most cost effective because of lower efficacy and high resistance rates [Buti et al., 2009]. There are now several other antiviral drugs available for the treatment of chronic HBV infection, most of which are superior to lamivudine because of higher efficacy and lower resistance rates. Thus, where available these more effective antivirals should be used.

The drugs available currently for the treatment of chronic infection can be divided into interferons and antivirals. The latter can be divided into a "lamivudine-like" and an "adefovirlike" group of antivirals. The first group comprises lamivudine, telbivudine, and entecavir, while the later comprises adefovir and tenofovir. Each of the antiviral substances is associated with a distinct mutation pattern which is associated with reduced drug efficacy or drug resistance, respectively [Tillmann, 2007].

The lamivudine-like substances can be characterized by their selection for mutants with a methionine to valine or methionine to isoleucine in the YMDD motif of the HBV-polymerase, named rtM204V or rtM204I, respectively. There was no association between substitution of either valine or isoleucine and outcome when no other treatment option was available [Enomoto et al. 2007]. Likewise, there is no evidence for a role of rtM204I vs. rtM204V concerning subsequent patient's clinical response when treated with adefovir or tenofovir [Tillmann, 2008]. This aspect, however, has changed with the availability of two other drugs known to select mutations in the YMDD motif, entecavir and telbivudine. The development of entecavir resistance in vivo seems to depend on the presence of the rtL180M-rtM204V [Tenney et al. 2004; Walsh et al., 2010]. In contrast, telbivudine mainly selects a rtM204I resistance mutation in vivo [Lai et al., 2007; Liaw et al., 2009]. However, studies concerning telbivudine have recruited most of their patients from Asia with genotype B or C dominance [Lai et al., 2007; Hou et al., 2008; Liaw et al., 2009].

There are currently eight HBV genotypes known which are endemic to different regions of the world. Genotype A dominates Northern Europe, but it is also found in North Africa and India. Genotypes B and C are prevalent in the Asian-Pacific area. Genotype D is found in the Mediterranean area, the Middle East, and India. Genotypes E-H have been isolated in samples from West Africa, the Americas, and France. [Norder et al., 2004].

While HBV-genotypes have been demonstrated to be relevant for the efficacy of interferon based therapies, there is no evidence at present that genotypes modify efficacy of nucleos(t)ide based therapies [Wiegand et al., 2008].

The purpose of this study was to analyse the pattern of mutation in the YMDD motif associated with lamivudine therapy in relation to HBV-genotypes. Mutation patterns were identified in 
relation to HBV-genotypes through a systematic literature review and confirmed the observations by molecular genetic analyses of two reference laboratories in Germany and Australia.

\section{Methods:}

\section{Literature review:}

The Medline database of the U.S. National Library of Medicine (PubMed) was screened for publications using keywords "HBV OR Hepatitis B", "YMDD", "genotype", and "lamivudine". All manuscripts published until June 2009 were considered. Data regarding lamivudine treated patients with mutations in the YMDD motif were extracted and analyzed in regard to mutation pattern on lamivudine.

Sources that did not contain the specific data for the analysis in the categories above were excluded from further analysis.

If information on genotyping was not included in the source, genotype was assumed according to today's knowledge on endemics of HBV-genotypes. I.e. Korea is known to almost exclusively harbor genotype " $\mathrm{C}$ " [Kim et al., 2007]. Thus, if no genotype was given, then Korean data was regarded as genotype " $\mathrm{C}$ ". Genotype was assumed in sources when such assumptions seem justifiable. For countries that are known for the appearance of multiple genotypes such as Canada, the US, and Australia data were not included without genotype specification.

\section{Mutation analysis from two databases:}

The most recent HBV polymerase/reverse transcriptase (RT) sequences, tested for the presence of drug resistance associated RT mutations, from 143 patients were extracted from the SeqHepB database [Yuen et al., 2007] located at the Victorian Infectious Diseases Reference Laboratory, Australia. Selection criteria were: first-time lamivudine monotherapy during sample collection, and presence of rtL80I/V, rtV173L, rtL180M and/or rtM204I/V in the HBV sequence.

Thirty seven sera of HBV-infected patients with lamivudine resistance were collected at the Department of Molecular Pathology, University Hospital of Tübingen, Germany, for diagnostic purposes and studied in accordance to national ethical principles. YMDD mutations were identified by sequencing of a region spanning the entire YMDD-motive from nt 467 to nt 845 (numbering according to GenBank accession no. 272478). In brief, HBV DNA was extracted from patient serum as described previously [Toan et al., 2006]. The HBV polymerase region was amplified by nested PCR using the following primer pairs: outer primer pair HBV-2003: 5'GCACCTGTATTCCCATCCC-3' and HBV-2380 5'-GGCCTGTTAACAGGAAGTT-3'; inner primer pair HBV-2046 5'-CCTATGGGAGTGGGCCTCAGT-3' HBV-2220 and CAAAAGAAAATTGGTAACAGCGGTA-3'. Reactions for first and second PCR were at $94^{\circ} \mathrm{C}$ for 30 seconds, $52^{\circ} \mathrm{C}$ for 30 seconds, and $72^{\circ} \mathrm{C}$ for 30 seconds followed by a final extension for 10 
minutes at $72^{\circ} \mathrm{C}$ for 35 cycles. Direct DNA sequencing of the PCR products on both strands using primers for nested PCR (HBV-2046 and HBV 2220) was performed as described previously [Song et al., 2003]. The sequences obtained were matched with the National Center for Biotechnology Information GenBank and compared with recently described HBV-prototypes (Accession No. for: HBV-A Z72478; HBV-B D00329; HBV-C X01587; HBV-D V01460; HBV-E X75657; HBV-F X75658; HBV-G AF160501) All samples were analysed in duplicate.

\section{Statistics:}

Data were calculated using Microsoft Excel. The level of association between HBV genotype and lamivudine-resistant patterns of different HBV mutants was evaluated using SPSS (12.0.1, SPSS, Chicago, Illinois, USA). The occurrence of rtM204I and rtM204V was determined as well as cooccurrence of both substitutions in the HBV sequences, and performed statistical analysis on the number of sequences with rtM204I present vs. rtM204l absent and rtM204V present vs. rtM204V absent, with co-occurrence being counted in presence for both. Furthermore, the frequency of co-occurrence of both patterns of substitutions among different genotypes was compared. When available the occurrence of rtL180M substitution was also evaluated. ChiSquare test of independence was used when appropriate.

\section{Results:}

\section{Literature Review:}

A total number of 72 publications were identified through the indicated search (see supplement table 1). All available publications till June 2009 were included. Twelve publications did not refer to patient related data, lamivudine therapy, or mutations in the YMDD motif at all. 23 publications referred to technical methods or did not link genotypes with information on amino acid substitution at amino acid position rtM204. Eight studies reported mutations in the YMDD motif, but did not differentiate the pattern of rtM204V vs. rtM204I.

Ten studies did not present specific information on HBV genotypes, but could be assumed due to almost unique genotype pattern in the respective countries. Seven studies [Paik et al., 2006; Lee et al., 2006; Lee et al., 2005; Joh et al., 2005; Hong et al., 2004; Kim et al., 2003; Gwak et al., 2007] presenting 147 patients originated from Korea and were therefore assumed as genotype C. Two studies presenting twelve patients from Greece and Turkey [Economou et al., 2005; Pai et al., 2005] were assumed as genotype D [Norder et al. 2004]. Ten patients from Poland presented by Gora-Gebka H et al. [2007] were assumed to be genotype A [Deterding et al., 2008].

Thus, 29 studies could be included, which reported on HBV-genotypes and pattern of rtM204I vs. rtM204V substitutions. These 29 studies represented 827 individual patients with either rtM204V or rtM204I substitutions: 110 cases with genotype $A, 173$ cases with genotype $B, 435$ cases with genotype $C$, and 109 cases with genotype $D$. 
Differences in the rtM204V/I substitution pattern could be identified. The dominant resistance mutation in genotype A was rtM204V (80.9\%), while genotype B, C, and D showed a preference of rtM204I (53.2\%, $77.0 \%$ and $56.8 \%$, respectively $(p<0.001)$. Co-presence of both rtM204I and rtM204V was significantly more frequently found in genotype $\mathrm{C}(19.8 \%)$ than in any of the other three genotypes $(<5 \%$; see table $1 a, b) .(p<0.001)$

Genotype B, C, and D all selected preferentially for the rtM204I substitution ( $>50 \%$ ); this was significantly different from genotype $A(p<0.001)$. However, genotype $C$ had a significantly higher prevalence of the rtM204l substitution than genotypes B and $D$, respectively $(p<0.001$, see table 1a \& b).

In order to rule out bias caused by the assumption of HBV genotypes in cases where data were not provided, the analysis was repeated without the cases with assumed genotypes. All findings that were significant in the initial analysis remained significant in the smaller analysis (data not shown).

The rtL180M substitution in relation to the rtM204V or rtM204I pattern and HBV-genotype

Only a few studies have reported on the amino acid substitution leucine to methionine at position 180 (rtL180M) [ Bozdayi et al., 2003; Kim et al. 2003; Economou et al., 2005; Li et al., 2005; Woo et al., 2007; Bottecchia et al., 2008; lacomi et al., 2009]. lacomi et al. [2009] and Bottecchia et al. [2008] reported 28 and 15 HBV-genotype A cases with rtL180M mutations, respectively. Notably, the rtM204V mutation was associated with the rtL180M mutation in all 38 cases. In contrast, only one of the five cases described with a rtM204I mutation was associated with the rtL180M mutation ( $p<0.001$, see table 2 ).

One study has reported the rtL180M substitution in relation to genotype B [Li et al., 2005]. The rtL180M was present in all 45 cases of rtM204V, while the frequency of rtL180M was only $43.8 \%$ (28/64; $p<0.001$, (see Table 2)) in cases with rtM204I.

Three studies reported on a total of 38 genotype $C$ cases in relation to YMDD changes and the rtL180M mutation [Kim et al. 2003; Woo et al., 2007; Bottecchia et al., 2008]. Similar to genotypes A and B, all ten cases of rtM204V also presented with a rtL180M change. However, cases of genotypes $A$ and $B$ with the rtM204l substitution were found infrequently with the rtL180M change, whilst the majority of genotype $C$ cases with rtM204I also harbored rtL180M (18/24, 75\%). The difference of rtL180M occurrence in relation to rtM204I and M204V was not significantly different within genotype $\mathrm{C}$ (see Table 2 ).

Three studies reported on genotype $D$ and its relation to the rtL180M and the rtM204V or rtM204I change [Bozdayi et al., 2003; Economou et al., 2005; lacomi et al., 2009]. 31/35 (88.6\%) patients infected with rtM204V also had rtL180M. This was significantly more frequent than in cases with rtM204I (12/41; 29.3\%; $p<0.001$, see Table 2).

The occurrence of rtL180M was significantly less frequently associated with rtM204I in genotype $B$ and genotype $D$ than genotype $C(p=0.018$, and $p<0.001$, respectively). Though only one of five genotype A cases infected with rtM204I also had a rtL180M. However, the frequency of rtM204I overall was too low to reach the level of significance (see Table 2). 
Additionally Li et al. [2005] presented six rtL180M positive patients without association to a rtM204V or rtM204l change, which could be due to prior famciclovir therapy; Bozdayi et al. [2003] reported the occurrence of rtL180M in co-mutation with the exchange of methionine against serine in position 204 (M204S). Patients from both studies were positive for genotype D.

\section{Lamivudine resistance associated substitution analysis from two databases:}

The University Hospital of Tübingen and the Victorian Infectious Diseases Reference Laboratory, Melbourne had information on 37 and 143 patients, respectively.

The Australian patients harbored genotype $A(n=39)$, genotype $B(n=27)$, genotype $C(n=36)$, and genotype $D(n=34)$. The remaining seven individuals were positive for genotype $F$ or $G$ and were not incorporated.

The German database mainly had patients infected with genotype $A(n=16)$ and $D(n=17)$. Two cases were infected with genotype $E$, one with genotype $C$, and one was not genotyped.

\section{Analysis of the "Melbourne" Database:}

Analysis of differences in "YMDD" mutation preference revealed a significant difference in the behavior of genotype A and B. As observed from the literature data, genotype A favors the rtM204V substitution (79.5\%), while genotype B is associated with rtM204I (75\%; $p<0.001)$.

The number of rtM204V positive cases was higher in genotype $\mathrm{C}$ than the number of cases with a rtM204I mutation (58.3\% versus $44.4 \%$, respectively). Genotype D on the other hand seemed to favor the selection of the rtM204I substitution (67.6\% vs. $38.2 \%)$ in line with the literature data. However, the findings in genotype $C$ and $D$ were not statistically significant, but showed a trend only $(p=0.059$ for the difference in rtM204l mutation frequency and $p=0.102$ for the difference in rtM204V mutation frequency and see table $3 a$ and $3 b$ ).

Eighty-seven (64\%) of the 137 patients positive for genotype A-D were positive for rtL180M , thus the rtL180M substitution was associated with the rtM204V change. This finding was significant in all genotypes (see table 4).

\section{Analysis of the "Tübingen" Database:}

Thirty of the 37 patients studied harbored the rtM204V change, which was associated with rtL180M in 26 of the cases, while only one of seven patients was identified with rtM204I that also harbored $r t L 180 M$. This difference was significant despite the small numbers $(p=0.001)$.

The profile of rtM204V change vs. rtM204I change was analysed in relation to HBV genotype. The rtM204V mutation was more dominant in genotype A $(93.7 \%)$ compared to Genotype D (70.6\%). This difference was not statistically significant $(p=0.1748$, see Table 5$)$. 


\section{Additional substitutions associated with lamivudine resistance mutation pattern in relation to HBV genotypes}

The additional substitution rtL80I, rtV173L, and $\mathrm{rtA181V/T}$ have been described to occur in relation to lamivudine resistance [Warner and Locarnini 2008; Warner et al., 2007; Delaney et al., 2003].

\section{Melbourne Dataset:}

Among the 143 patients, 39 had a rtL80I/V mutation (rtL80I in 21 and rtL80V in 18 cases, respectively), and 21 patients had a rtV173L mutation. There was no difference in distribution of rtL80I vs. rtL80V. Only one patient was found in whom both rtL80I/V and rtV173L $(p=0.005)$ were detected. Furthermore, there was a striking difference depending on genotype in relation to both rtL80I/V and rtV173L (s. Table 6).

\section{Tübingen Dataset:}

Among the 37 patients analysed, whilst four were found to be infected with rtL80I, four had rtV173L, one had rtA181V and none had rtA181T. There was no significant difference, but rtL80I was more frequent in genotype $D(3 / 17,17.6 \%)$ than genotype $A(1 / 16,6.25 \%$; not significant [n.s.]) and rtV173L showed the same distribution. However, in none of the cases was rtL80I cooccurring with rtV173L. The rtV173L substitution was associated solely with the selection of rtM204V $(4 / 30,13.3 \%)$, while the rtL80I was present in 1/7 (14.2\%) cases with rtM204I and in $3 / 27$ (11.1\%; n.s.; s. Table 7) individuals with rtM204V.

\section{Exploratory Analysis of changes in the surface antigen (HBsAg) in relation to polymerase changes and HBV genotype}

The HBV genome is composed of four overlapping open reading frames (ORF). The polymerase and surface protein ORF's overlap, thus each mutation in the polymerase could potentially influence two codons on the HBsAg. Four polymerase amino acid positions were analysed for this aspect: a.) rtL80 corresponding to sG71 and sY72; b.) rtV173 corresponding to SE/V164 and sW/L165; c.) rtL180 corresponding to sS171 and sW172; and d.) rtM204 corresponding to sl195 and sW196. This information was available in 136 patients.

The polymerase changes at rtL80 and rtL180 are not associated with an amino acid change in the s-gene, whilst the rtV173L change is associated with a sE164D substitution in all cases. The rtV173L mutation was absent in genotype B and so not surprising then, the SE164D change was not observed.

Amino acid substitutions at rtM204 resulted in a more complex pattern of $\mathrm{HBsAg}$ changes, which is more dependent on the rtM204 mutation than on the HBV-genotype. The rtM204I does 
not alter the sl195, while the rtM204V always results in a change to sl195M, which is independent of genotype. sW196 can be changed to a leucine (L), serine (S), or stop codon. The majority of patients with the rtM204I mutation harbour a sW196L mutation, while the majority of rtM204V mutation patient harbour the sW196 wild-type. Other mutations were relatively rare (see table 8 ).

\section{Discussion:}

The role of the different mutation patterns had no clinical relevance when lamivudine and adefovir were the only therapeutic options. However, this relevance of the mutation pattern might change with the availability of telbivudine and entecavir. Resistance to these two drugs is associated with "opposite" changes in the YMDD motif: rtM204V is associated with entecavir resistance, and rtM204l is associated with telbivudine resistance [Tenney et al., 2004; Papatheodoridis and Deutsch, 2008; Liaw et al., 2008]. No data on the role of genotype and different mutation pattern concerning response to entecavir and telbivudine are available; further analysis of the studies with entecavir and telbivudine and substitution pattern and frequency are warranted. A possible scenario is that resistance to telbivudine may be delayed in Genotype "A" patients, while resistance to entecavir might be less likely in case of genotype B and $C$, even after pre-treatment with lamivudine. There was one study which actually suggested worse response to entecavir in the setting of rtM204V vs. rtM204I mutations [Suzuki et al., 2008].

Although lamivudine is considered obsolete according to guidelines from several clinical practice regions [Lok and McMahon 2004], lamivudine remains today's mostly used and cheapest available drug against HBV infection. Lamivudine should not be used but substituted by more effective therapies with higher antiviral activity and lower resistance rates. As discussed above, entecavir and telbivudine have opposite preference in regard to "YMDD" motif pattern. Therefore lamivudine use carries the risk to burn both medications for future use because it selects both mutational patterns - rtM204I and rtM204V - in all major genotypes. This would limit the chance of a successful treatment with entecavir in case of a rtM204V mutation and most likely will impact the chance of responding to telbivudine in case of a rtM204I. As this has not been studied formally in either telbivudine or entecavir, this remains a hypothesis at present.

In addition, the mutation pattern was evaluated independently from the YMDD motif, and also found strong genotype dependency. The Tübingen dataset, however, was too small to confirm the findings from the Melbourne database. The level of significance, however, was different for the different genotypes concerning the rtL80I/ $V$ mutation.

This study demonstrates for the first time that there is a significant difference in mutation pattern between the four major genotypes of HBV. The strength of this study is the concordance of RT mutation patterns found in the three different datasets. Nonetheless, the limitation of this study is that it was a retrospective analysis. Likewise, data on $\mathrm{HBeAg}$ status and coinfection with other viral pathogens (e.g. HIV or HCV) were not available for the majority of the reviewed 
papers, and were therefore also not included for the confirmation part of the study using data from Australia and Germany. Another limitation is that methods to detect changes in the YMDD motif were heterogeneous in the different studies, which lead to differences in the rate that minor species substitutions are detected [Woo et al., 2008]. However, the initial literature based observation was confirmed in the prospective analysis of the genome databases from two reference laboratories.

In conclusion there is a difference in the pattern of YMDD mutants between the major HBVgenotypes. Future studies are needed to prove if this difference in mutational pattern will modify frequency of resistance development against telbivudine or entecavir, respectively. Thus, it would be valuable to study resistance emergence in regard to telbivudine and entecavir in relation to HBV genotypes.

\section{References:}

Bottecchia M, Souto FJ, O KM, Amendola M, Brandao CE, Niel C, Gomes SA. 2008. Hepatitis B virus genotypes and resistance mutations in patients under long term lamivudine therapy: characterization of genotype G in Brazil. BMC Microbiol 8:11.

Bozdayi AM, Uzunalimoglu O, Turkyilmaz AR, Aslan N, Sezgin O, Sahin T, Bozdayi G, Cinar K, Pai SB, Pai R, Bozkaya H, Karayalçin S, Yurdaydin C, Schinazi RF. 2003 YSDD: a novel mutation in HBV DNA polymerase confers clinical resistance to lamivudine. J Viral Hepat 10:256-265.

Buti M, Brosa M, Casado MA, Rueda M, Esteban R. 2009. Modeling the cost-effectiveness of different oral antiviral therapies in patients with chronic hepatitis B. J Hepatol 51:640-646.

Cornberg M, Protzer U, Dollinger MM, Petersen J, Wedemeyer H, Berg T, Jilg W, Erhardt A, Wirth S, Schirmacher P, Fleig WE, Manns MP. 2007. Prophylaxis, diagnosis and therapy of hepatitis $B$ virus (HBV) infection: the German guidelines for the management of HBV infection. Z Gastroenterol 45:1281-1328.

Delaney WE, Yang H, Westland CE, Das K, Arnold E, Gibbs CS, Miller MD, Xiong S. 2003. The hepatitis $B$ virus polymerase mutation $r \mathrm{~V} 173 \mathrm{~L}$ is selected during lamivudine therapy and enhances viral replication in vitro. J Virol 77:11833-11841.

Deterding K, Constantinescu I, Nedelcu FD, Gervain J, Nemecek V, Srtunecky O, Vince A, Grgurevic I, Bielawski KP, Zalewska M, Bock T, Ambrozaitis A, Stanczak J, Takács M, Chulanov V, Slusarczyk J, Drazd'áková M, Wiegand J, Cornberg M, Manns MP, Wedemeyer H. 2008. Prevalence of HBV genotypes in Central and Eastern Europe. J Med Virol 80:17071711.

Economou M, Manolakopoulos S, Trikalinos TA, Filis S, Bethanis S, Tzourmakliotis D, Avgerinos A, Raptis S, Tsianos EV. 2005. Interferon-alpha plus lamivudine vs lamivudine reduces breakthroughs, but does not affect sustained response in $\mathrm{HBeAg}$ negative chronic hepatitis B. World J Gastroenterol 11:5882-5887. 
Enomoto M, Tamori A, Kohmoto MT, Morikawa H, Habu D, Sakaguchi H, Takeda T, Seki S, Kawada N, Shiomi S, Nishiguchi S. 2007. Mutational patterns of hepatitis B virus genome and clinical outcomes after emergence of drug-resistant variants during lamivudine therapy: analyses of the polymerase gene and full-length sequences. J Med Virol 79:16641670.

Gora-Gebka M, Liberek A, Charmuszko U, Sikorska-Wisniewska G, Szlagatys-Sidorkiewicz A, Korzon M, Bielawski K. 2007. [HBV gene variants and polymerse gene mutations in children with chronic hepatitis B in the course of the antiviral therapy]. Med Wieku Rozwoj 11:367-371.

Gwak GY, Huh W, Lee DH, Choi MS, Lee JH, Koh KC, Kim SJ, Joh JW, Oh HY. 2007: The incidence and clinical outcome of YMDD mutants in hepatitis B surface antigen-positive renal allograft recipients after prolonged lamivudine therapy. Transplant Proc 39:3121-3126.

Hong SP, Kim NK, Hwang SG, Chung HJ, Kim S, Han JH, Kim HT, Rim KS, Kang MS, Yoo W, Kim SO. 2004. Detection of hepatitis $B$ virus YMDD variants using mass spectrometric analysis of oligonucleotide fragments. J Hepatol 40:837-844.

Hou J, Yin YK, Xu D, Tan D, Niu J, Zhou X, Wang Y, Zhu L, He Y, Ren H, Wan M, Chen C, Wu S, Chen Y, Xu J, Wang Q, Wei L, Chao G, Constance BF, Harb G, Brown NA, Jia J. 2008. Telbivudine versus lamivudine in Chinese patients with chronic hepatitis B: Results at 1 year of a randomized, double-blind trial. Hepatology 47:447-454.

lacomi F, Vincenti D, Vairo F, Solmone M, Mariano A, Piselli P, Puro V, Capobianchi MR, Antonucci G. 2009. Effect of HIV co-infection on mutation patterns of HBV in patients with lamivudine-resistant chronic hepatitis B. J Med Virol 81:1151-1156.

Joh JW, Lee HH, Park JW, Lee DH, Yoo BC, Lee KW, Kim SJ. 2005. Genotypic resistance of hepatitis B virus to lamivudine in renal transplant recipients. Transplant Proc 37:12351237.

Kim KH, Lee KH, Chang HY, Ahn SH, Tong S, Yoon YJ, Seong BL, Kim SI, Han KH. 2003. Evolution of hepatitis $B$ virus sequence from a liver transplant recipient with rapid breakthrough despite hepatitis B immune globulin prophylaxis and lamivudine therapy. J Med Virol 71:367-375.

Kim H, Jee YM, Song BC, Shin JW, Yang SH, Mun HS, Kim HJ, Oh EJ, Yoon JH, Kim YJ, Lee HS, Hwang ES, Cha CY, Kook YH, Kim BJ. 2007. Molecular epidemiology of hepatitis B virus (HBV) genotypes and serotypes in patients with chronic HBV infection in Korea. Intervirology 50:52-7.

Lai CL, Gane E, Liaw YF, Hsu CW, Thongsawat S, Wang Y, Chen Y, Heathcote EJ, Rasenack J, Bzowej N, Naoumov NV, Di Bisceglie AM, Zeuzem S, Moon YM, Goodman Z, Chao G, Constance BF, Brown NA; Globe Study Group. 2007. Telbivudine versus lamivudine in patients with chronic hepatitis B. N Engl J Med 357:2576-2588. 
Liaw YF, Gane E, Leung N, Zeuzem S, Wang Y, Lai CL, Heathcote EJ, Manns M, Bzowej N, Niu J , Han SH, Hwang SG, Cakaloglu Y, Tong MJ, Papatheodoridis G, Chen Y, Brown NA, Albanis E, Galil K, Naoumov NV; GLOBE Study Group. 2009. 2-Year GLOBE trial results: telbivudine Is superior to lamivudine in patients with chronic hepatitis B. Gastroenterology 136:486-495.

Lee SY, Choi MS, Lee D, Lee JH, Koh KC, Paik SW, Yoo BC. 2005. Overlapping gene mutations of hepatitis $B$ virus in a chronic hepatitis B patient with hepatitis B surface antigen loss during lamivudine therapy. J Korean Med Sci 20:433-437.

Lee CH, Kim SO, Byun KS, Moon MS, Kim EO, Yeon JE, Yoo W, Hong SP. 2006. Predominance of hepatitis B virus YMDD mutants is prognostic of viral DNA breakthrough. Gastroenterology 130:1144-1152.

Li MW, Hou W, Wo JE, Liu KZ. 2005. Character of HBV (hepatitis B virus) polymerase gene $\mathrm{rtM} 204 \mathrm{~V} / \mathrm{I}$ and rtL180M mutation in patients with lamivudine resistance. J Zhejiang Univ Sci B 6:664-667.

Lok AS, McMahon BJ. 2004. Chronic hepatitis B: update of recommendations. Hepatology 2004, 39(3):857-861.

Norder H, Courouce AM, Coursaget P, Echevarria JM, Lee SD, Mushahwar IK, Robertson BH, Locarnini S, Magnius LO. 2004. Genetic diversity of hepatitis B virus strains derived worldwide: genotypes, subgenotypes, and HBsAg subtypes. Intervirology 47:289-309.

Pai SB, Bozdayi AM, Pai RB, Beker T, Sarioglu M, Turkyilmaz AR, Grier J, Yurdaydin C, Schinazi RF. 2005. Emergence of a novel mutation in the FLLA region of hepatitis $B$ virus during lamivudine therapy. Antimicrob Agents Chemother 49:2618-2624.

Paik YH, Han KH, Hong SP, Lee HW, Lee KS, Kim SO, Shin JE, Ahn SH, Chon CY, Moon YM. 2006. The clinical impact of early detection of the YMDD mutant on the outcomes of long-term lamivudine therapy in patients with chronic hepatitis B. Antivir Ther 11:447-455.

Papatheodoridis GV, Deutsch M. 2008. Resistance issues in treating chronic hepatitis B. Future Microbiol 3:525-538.

Song LH, Binh VQ, Duy DN, Juliger S, Bock TC, Luty AJ, Kremsner PG, Kun JF. 2003. Mannosebinding lectin gene polymorphisms and hepatitis $B$ virus infection in Vietnamese patients. Mutat Res 522:119-125.

Suzuki F, Suzuki Y, Akuta N, Yatsuji H, Sezaki H, Arase Y, Kawamura Y, Hosaka T, Kobayashi M, Ikeda K, Kobayashi M, Watahiki S, Kumada H. 2008. Changes in viral loads of lamivudineresistant mutants during entecavir therapy. Hepatol Res 38:132-140.

Tenney DJ, Levine SM, Rose RE, Walsh AW, Weinheimer SP, Discotto L, Plym M, Pokornowski K, Yu CF, Angus P, Ayres A, Bartholomeusz A, Sievert W, Thompson G, Warner N, Locarnini S, Colonno RJ. 2004. Clinical emergence of entecavir-resistant hepatitis $B$ virus requires additional substitutions in virus already resistant to Lamivudine. Antimicrob Agents Chemother 48:3498-507. 
Tillmann HL, Trautwein C, Bock T, Boker KH, Jackel E, Glowienka M, Oldhafer K, Bruns I, Gauthier J, Condreay LD, Raab HR, Manns MP. 1999. Mutational pattern of hepatitis B virus on sequential therapy with famciclovir and lamivudine in patients with hepatitis B virus reinfection occurring under $\mathrm{HBIg}$ immunoglobulin after liver transplantation. Hepatology 30:244-256.

Tillmann HL. 2007. Pradefovir, a liver-targeted prodrug of adefovir against HBV infection. Curr Opin Investig Drugs 8:682-690.

Tillmann HL. 2008. The treatment of chronic hepatitis B: Focus on adefovir-like antivirals. Ther Clin Risk Manag 4:797-802.

Toan NL, Song le H, Kremsner PG, Duy DN, Binh VQ, Koeberlein B, Kaiser S, Kandolf R, Torresi J, Bock CT. 2006. Impact of the hepatitis $B$ virus genotype and genotype mixtures on the course of liver disease in Vietnam. Hepatology 43:1375-1384.

Walsh AW, Langley DR, Colonno RJ, Tenney DJ. 2010. Mechanistic characterization and molecular modeling of hepatitis B virus polymerase resistance to entecavir. PLoS One 5:e9195.

Warner N, Locarnini S, Kuiper M, Bartholomeusz A, Ayres A, Yuen L, Shaw T. 2007. The L80I substitution in the reverse transcriptase domain of the hepatitis $B$ virus polymerase is associated with lamivudine resistance and enhanced viral replication in vitro. Antimicrob Agents Chemother 51:2285-2292.

Warner N, Locarnini S. 2008. The antiviral drug selected hepatitis B virus rtA181T/sW172* mutant has a dominant negative secretion defect and alters the typical profile of viral rebound. Hepatology 48:88-98.

Wiegand J, Hasenclever D, Tillmann HL. 2008. Should treatment of hepatitis B depend on hepatitis B virus genotypes? A hypothesis generated from an explorative analysis of published evidence. Antivir Ther 13:211-220.

Woo HY, Park H, Kim BI, Jeon WK, Cho YK, Kim YJ. 2007. Comparison of mass spectrometric analysis and TRUGENE HBV genotyping for monitoring lamivudine resistance in chronic hepatitis B patients. Antivir Ther 12:7-13.

Woo HY, Park H, Kim BI, Jeon WK, Kim YJ. 2008. Evaluation of dual priming oligonucleotidebased multiplex PCR for detection of HBV YMDD mutants. Arch Virol 153:2019-2025.

Yuen LK, Ayres A, Littlejohn M, Colledge D, Edgely A, Maskill WJ, Locarnini SA, Bartholomeusz A. 2007. SeqHepB: a sequence analysis program and relational database system for chronic hepatitis B. Antiviral Res 75:64-74. 
Table 1a: Distribution of YMDD mutations in various genotypes according to literature review

\begin{tabular}{|l|l|l|l|}
\hline & rtM204I (n=515) & rtM204V (n=410) & $\begin{array}{l}\text { Mixed } \\
(\text { rtM204V\&rtM204I) }\end{array}$ \\
\hline Genotype A (n=110) & $23.6 \%(26)$ & $80.9 \%(89)$ & $4.5 \%(n=5)$ \\
\hline Genotype B (n=173) & $53.2 \%(92)$ & $49.7 \%(86)$ & $2.9 \%(n=5)$ \\
\hline Genotype C (n=435) & $77.0 \%(335)$ & $42,8 \%(186)$ & $19.8 \%(n=86)$ \\
\hline Genotype D (n=109) & $56.8 \%(62)$ & $45.0 \%(49)$ & $1.8 \%(n=2)$ \\
\hline
\end{tabular}

Table 1b: Comparison between different genotypes in the literature review. p-values for frequency of the rtM204V, the rtM204I, and the co-presence of both substitutions.

\begin{tabular}{|l|l|l|l|}
\hline rtM204I & Genotype B & Genotype C & Genotype D \\
\hline Genotype A & $\mathbf{p}<0.001$ & $\mathbf{p}<0.001$ & $\mathbf{p}<0.001$ \\
\hline Genotype B & & $\mathbf{p}<0.001$ & $\mathbf{p}=0.623$ \\
\hline Genotype C & $\mathbf{p}<0.001$ & & $\mathbf{p}<0.001$ \\
\hline
\end{tabular}

\begin{tabular}{|l|l|l|l|}
\hline rtM204V & Genotype B & Genotype C & Genotype D \\
\hline Genotype A & $\mathbf{p}<0.001$ & $\mathbf{p}<0.001$ & $\mathbf{p}<0.001$ \\
\hline Genotype B & & $p=0.143$ & $p=0.464$ \\
\hline Genotype C & $p=0.143$ & & $p=0.760$ \\
\hline
\end{tabular}

\begin{tabular}{|l|l|l|l|}
\hline rtM204I\&V & Genotype B & Genotype C & Genotype D \\
\hline Genotype A & $p=0.518$ & $\mathbf{p}<0.001$ & $p=0.446$ \\
\hline Genotype B & & $\mathbf{p}<0.001$ & $p=0.710$ \\
\hline Genotype C & $\mathbf{p}<0.001$ & & $\mathbf{p}<0.001$ \\
\hline
\end{tabular}

\footnotetext{
* please note, those with mixed infection were counted twice: once for rtM204I and once for rtM20V. Thus, the sum of patients with rtM204I, rtM204I, and mixed rtM204V/l are greater than the total number of patients in each line.
} 
Table 2: rtL180M mutation reported in connection with YMDD motive according to the literature review. P-values reflect the level of significance for the difference for rtL180M occurrence in relation to rtM204V vs. rtM204I for each genotype individually.

\begin{tabular}{|l|l|l|l|l|l|l|l|}
\hline Genotype & $\begin{array}{l}\text { Number of } \\
\text { Studies } \\
\text { reporting }\end{array}$ & $\begin{array}{l}\text { Total } \\
\text { number of } \\
\text { patients }\end{array}$ & $\begin{array}{l}\text { rtM204I } \\
\text { without } \\
\text { rtL180M }\end{array}$ & $\begin{array}{l}\text { rtL180M } \\
\text { +rtM204I }\end{array}$ & $\begin{array}{l}\text { rtM204V } \\
\text { without } \\
\text { rtL180M }\end{array}$ & $\begin{array}{l}\text { rtL180M } \\
\text { +rtM204V }\end{array}$ & $p$-values \\
\hline A & $2^{\dagger}$ & 43 & $4 / 5(80 \%)$ & $1 / 5(20 \%)$ & $\begin{array}{l}0 / 38 \\
(0 \%)\end{array}$ & $38 / 38(100 \%)$ & $p<0.001$ \\
\hline B & $1^{\ddagger}$ & 109 & $36 / 64(56.2 \%)$ & $28 / 64(43.8 \%)$ & $\begin{array}{l}0 / 45 \\
(0 \%)\end{array}$ & $45 / 45(100 \%)$ & $p<0.001$ \\
\hline C & $3^{\S}$ & $34^{*}$ & $6 / 24(25.0 \%)$ & $18 / 24(75.0 \%)$ & $\begin{array}{l}0 / 10 \\
(0 \%)\end{array}$ & $10 / 10(100 \%)$ & $p=0.148$ \\
\hline D & $33^{* *}$ & 76 & $29 / 41(70.7 \%)$ & $12 / 41(29.3 \%)$ & $\begin{array}{l}4 / 35 \\
(11.4 \%)\end{array}$ & $31 / 35(88.6 \%)$ & $p<0.001$ \\
\hline
\end{tabular}

*Truegene results from Woo et al. [2007].

\footnotetext{
† [Bottecchia et al., 2008; lacomi et al., 2009]

${ }^{\ddagger}$ [Li e tal., 2005]

${ }^{\S}$ [Kim et al. 2003; Woo et al., 2007; Bottecchia et al., 2008]

${ }^{* *}$ [Bozdayi et al., 2003, Economou et al., 2005; lacomi et al., 2009]
} 
Table 3a, sequence analysis: Distribution of YMDD-mutations in relation to HBV genotypes in the Melbourne cohort ( $p<0.001$ overall).

\begin{tabular}{|l|l|l|l|}
\hline & rtM204I $(n=69)$ & rtM204V $(n=72)$ & Mixed $(n=4)^{+\dagger}$ \\
\hline Genotype A (n=39) & $23.1 \% *(n=9)$ & $79.5 \% *(n=31)$ & $2.5 \%(n=1)$ \\
\hline Genotype B $(n=28)$ & $75 \%^{*}(n=21)$ & $25 \% *(n=7)$ & $0 \%(n=0)$ \\
\hline Genotype C (n=36) & $44.4 \%(n=16)$ & $58.3 \%(n=21)$ & $2.8 \%(n=1)$ \\
\hline Genotype D (n=34) & $67.6 \%(n=23)$ & $38.2 \%(n=13)$ & $5.9 \%(n=2)$ \\
\hline
\end{tabular}

Table 3b, sequence analysis: $p$-values for difference in distribution of YMDD-mutations regarding genotype in the Melbourne cohort

\begin{tabular}{|l|l|l|l|}
\hline rtM204I & Genotype B & Genotype C & Genotype D \\
\hline Genotype A & $\mathbf{P}<\mathbf{0 . 0 0 1}$ & $\mathbf{p}=0.085$ & $\mathbf{p}=\mathbf{0 . 0 0 1}$ \\
\hline Genotype B & & $\mathbf{p}=\mathbf{0 . 0 1 0}$ & $\mathbf{p}=0.408$ \\
\hline Genotype C & $\mathbf{P}=\mathbf{0 . 0 1 0}$ & & $\mathbf{p}=0.059$ \\
\hline
\end{tabular}

\begin{tabular}{|l|l|l|l|}
\hline rtM204V & Genotype B & Genotype C & Genotype D \\
\hline Genotype A & $\mathbf{P}<\mathbf{0 . 0 0 1}$ & $\mathbf{p}=0.078$ & $\mathbf{p}=\mathbf{0 . 0 0 1}$ \\
\hline Genotype B & & $\mathbf{p}=\mathbf{0 . 0 0 5}$ & $\mathbf{p}=0.266$ \\
\hline Genotype C & $\mathbf{P}=\mathbf{0 . 0 0 5}$ & & $\mathbf{p}=0.102$ \\
\hline
\end{tabular}

\begin{tabular}{|l|l|l|l|}
\hline rtM204I\&V & Genotype B & Genotype C & Genotype D \\
\hline Genotype A & $\mathrm{P}=1$ & $\mathrm{p}=1$ & $\mathrm{p}=0.595$ \\
\hline Genotype B & & $\mathrm{p}=1$ & $\mathrm{p}=0.498$ \\
\hline Genotype C & $\mathrm{P}=1$ & & $\mathrm{p}=0.609$ \\
\hline
\end{tabular}

\footnotetext{
${ }^{{ }^{+\dagger}}$ please note, those with mixed infection were counted twice: once for rtM204I and once for rtM20V. Thus, the sum of patients with rtM204I, rtM204I, and mixed rtM204V/l are greater than the total number of patients in each line.
} 
1

2

Table 4: Distribution of rtL180M mutation in relation to genotypes and rtM204I vs. rtM204V.

\begin{tabular}{|c|c|c|c|c|c|c|}
\hline & $\begin{array}{c}\text { rtM204I } \\
\text { without } \\
\text { L180 }\end{array}$ & $\begin{array}{c}\text { rtM204I } \\
+ \\
\text { rtL180M }\end{array}$ & $\begin{array}{l}\text { rtM204V } \\
\text { without } \\
\text { rtL180M }\end{array}$ & $\begin{array}{c}\text { rtM204V } \\
+ \\
\text { rtL180M }\end{array}$ & $\begin{array}{c}\text { rtM204I/V } \\
\text { without } \\
\text { L180 }\end{array}$ & $\begin{array}{c}\text { rtM204I/V } \\
+ \\
\text { L180 }\end{array}$ \\
\hline $\begin{array}{l}\text { Total }(n=143) \\
p<0,001\end{array}$ & $47 / 65$ & $18 / 65$ & $1 / 74$ & $73 / 74$ & $0 / 4$ & $4 / 4$ \\
\hline $\begin{array}{l}\text { Genotype A ( } n=39) \\
p<0.001\end{array}$ & $7 / 8$ & $1 / 8$ & 0 & $30 / 30$ & $0 / 1$ & $1 / 1$ \\
\hline $\begin{array}{l}\text { Genotype B }(n=28) \\
p<0.001\end{array}$ & $19 / 20$ & $1 / 20$ & $0 / 6$ & $6 / 6$ & $0 / 0$ & $0 / 0$ \\
\hline $\begin{array}{l}\text { Genotype C }(n=36) \\
p<0.001\end{array}$ & $10 / 15$ & $5 / 15$ & $1 / 20$ & $19 / 20$ & $0 / 1$ & $1 / 1$ \\
\hline $\begin{array}{l}\text { Genotype } \\
(n=34) p=0.005\end{array}$ & $11 / 21$ & $10 / 21$ & $0 / 11$ & $11 / 11$ & 0 & $2 / 2$ \\
\hline
\end{tabular}


Table 5, sequence analysis: Distribution of YMDD-mutation in the Tübingen collective: No mixed rtM204I plus rtM204V cases were identified in the Tübingen database

\begin{tabular}{|l|l|l|}
\hline Genotype & rtM204I & rtM204V \\
\hline Genotype A $(n=16)$ & $6.3 \%(n=1)$ & $93.7 \%(n=15)$ \\
\hline Genotype D $(n=17)$ & $29.4 \%(n=5)$ & $70.6 \%(n=12)$ \\
\hline \multicolumn{2}{|l|}{$P=0.17$} \\
\hline
\end{tabular}


Table 6a: Mutation frequency of $\mathrm{rtL80V/I}$ und $\mathrm{rtV} 173 \mathrm{~L}$ in relation to genotypes within the Melbourne Database and corresponding p-values comparing the four different major genotypes.

\begin{tabular}{|l|l|l|}
\hline & rtL80V/I & rtV173L \\
\hline Genotype A (n=39) & $0(0 \%)$ & $8(20.5 \%)$ \\
\hline Genotype B (n=27) & $13(48.1 \%)$ & $0(0 \%)$ \\
\hline Genotype C (n=36) & $13(36.1 \%)$ & $5(13.9 \%)$ \\
\hline Genotype D (n=34) & $13(38.2 \%)$ & $8(23.5 \%)$ \\
\hline
\end{tabular}

\begin{tabular}{|l|l|l|l|}
\hline rtL80V/I & Genotype B & Genotype C & Genotype D \\
\hline Genotype A & $\mathbf{p}<\mathbf{0 . 0 0 1}$ & $\mathbf{p}<0.001$ & $\mathbf{p}<0.001$ \\
\hline Genotype B & & $\mathrm{p}=0.48$ & $\mathrm{p}=0.61$ \\
\hline Genotype C & & & $\mathrm{p}=0.95$ \\
\hline
\end{tabular}

\begin{tabular}{|l|l|l|l|}
\hline rtV173L & Genotype B & Genotype C & Genotype D \\
\hline Genotype A & $\mathbf{p}=\mathbf{0 . 0 3}$ & $\mathrm{p}=0.65$ & $\mathrm{p}=0.98$ \\
\hline Genotype B & & $\mathrm{p}=0.12$ & $\mathbf{p = 0 . 0 2}$ \\
\hline Genotype C & $\mathrm{p}=0.12$ & & 0.47 \\
\hline
\end{tabular}


Table 7: Mutation frequency of rtL80V/l und rtV173L in relation to genotypes within the Tübingen Database; no significant differences.

\begin{tabular}{|l|c|c|}
\hline & rtL80V/l & rtV173L \\
\hline$A(n=16)$ & $1(6.25 \%)$ & $1(6.25 \%)$ \\
\hline$D(n=17)$ & $3(17.6 \%)$ & $3(17.6 \%)$ \\
\hline
\end{tabular}


Table 8: sW196 mutation in relation to HBV genotypes and rtM204 mutation.

\begin{tabular}{|c|c|c|c|c|c|}
\hline \multicolumn{2}{|c|}{ Amino acid at } & \multicolumn{4}{c|}{ HBV-Genotpye } \\
\hline $\begin{array}{c}\text { "rt" position } \\
\text { rtM204 }\end{array}$ & $\begin{array}{c}\text { "sAg"position } \\
\text { W196 }\end{array}$ & $\begin{array}{c}\text { A } \\
(n=8)\end{array}$ & $\begin{array}{c}\text { B } \\
(n=20)\end{array}$ & $\begin{array}{c}\text { C } \\
(n=15)\end{array}$ & $\begin{array}{c}\text { D } \\
(n=21)\end{array}$ \\
\hline \multirow{4}{*}{$\begin{array}{c}\text { rtM204I } \\
\text { (n=64) }\end{array}$} & W196L & $\mathbf{6}$ & $\mathbf{1 4}$ & $\mathbf{1 2}$ & 18 \\
\cline { 2 - 6 } & W196S & & 4 & & 2 \\
\cline { 2 - 6 } & W196* & $\mathbf{2}$ & $\mathbf{1}$ & $\mathbf{1}$ & 1 \\
\cline { 2 - 6 } & W196L/ & & & 2 & \\
\cline { 2 - 6 } & W196S & & & & \\
\hline
\end{tabular}

\begin{tabular}{|c|c|c|c|c|c|}
\hline $\begin{array}{l}\text { "rt" position } \\
\text { rtM204 }\end{array}$ & $\begin{array}{l}\text { "sAg"position } \\
\text { W196 }\end{array}$ & $\begin{array}{c}A \\
(n=30)\end{array}$ & $\underset{(n=6)}{B}$ & $\begin{array}{c}C \\
(n=20)\end{array}$ & $\begin{array}{c}D \\
(n=11)\end{array}$ \\
\hline \multirow{2}{*}{$\begin{array}{c}\text { rtM204V } \\
(n=67)\end{array}$} & W196 & 29 & 6 & 20 & 11 \\
\hline & W196/ W196L & 1 & & & \\
\hline
\end{tabular}

\begin{tabular}{|c|c|c|c|c|c|}
\hline $\begin{array}{c}\text { "rt" position } \\
\text { rtM204 }\end{array}$ & $\begin{array}{c}\text { "sAg"position } \\
\text { W196 }\end{array}$ & $\begin{array}{c}\text { A } \\
(\mathbf{n}=1)\end{array}$ & $\begin{array}{c}\text { B } \\
(\mathbf{n}=\mathbf{0})\end{array}$ & $\begin{array}{c}\text { C } \\
(\mathbf{n}=\mathbf{1})\end{array}$ & $\begin{array}{c}\text { D } \\
(\mathbf{n}=\mathbf{2})\end{array}$ \\
\hline $\begin{array}{c}\text { rtM204I/V } \\
(\mathbf{n}=\mathbf{4})\end{array}$ & W196/W196L & 1 & & 1 & 2 \\
\hline
\end{tabular}

* Stop codon,

cells with a light grey are those with sAg wild type amino acid sAgW196. rtM204V is mostly associated with the wild type amino acid sAgW196, while rtM204I is always associated with a mutated HBsAg amino acid sequence at position 196. 
Supplement Table 1: Studies indicated in the PubMed-Search using the search terms "HBV OR Hepatitis B", "YMDD", "genotype", and "lamivudine"

1. Woo HY, Park H, Kim BI, Jeon WK, Cho YK, Kim YJ. Comparison of mass spectrometric analysis and TRUGENE HBV genotyping for monitoring lamivudine resistance in chronic hepatitis B patients. Antivir Ther. 2007;12(1):7-13.

2. Yuen MF, Sablon E, Libbrecht E, Van De Velde H, Wong DK, Fung J, Wong BC, Lai CL. Significance of viral load, core promoter/precore mutations and specific sequences of polymerase gene in HBVinfected patients on 3-year lamivudine treatment. Antivir Ther. 2006;11(6):779-86.

4. Kobayashi M, Suzuki F, Akuta N, Suzuki Y, Arase Y, Ikeda K, Hosaka T, Sezaki H, Kobayashi M, Iwasaki S, Sato J, Watahiki S, Miyakawa Y, Kumada H. Response to long-term lamivudine treatment in patients infected with hepatitis B virus genotypes A, B, and C. J Med Virol. 2006 Oct;78(10):1276-83. 5. Paik YH, Han KH, Hong SP, Lee HW, Lee KS, Kim SO, Shin JE, Ahn SH, Chon CY, Moon YM. The clinical impact of early detection of the YMDD mutant on the outcomes of long-term lamivudine therapy in patients with chronic hepatitis B. Ther. 2006;11(4):447-55.

6. Orito E, Fujiwara K, Tanaka Y, Yuen MF, Lai CL, Kato T, Sugauchi F, Kusakabe A, Sata M, Okanoue T, Niitsuma H, Sakugawa H, Hasegawa I, Mizokami M. A case-control study of response to lamivudine therapy for 2 years in Japanese and Chinese patients chronically infected with hepatitis $B$ virus of genotypes Bj, Ba and C. Hepatol Res. 2006 Jun;35(2):127-34.

7. Lee CH, Kim SO, Byun KS, Moon MS, Kim EO, Yeon JE, Yoo W, Hong SP. Predominance of hepatitis $B$ virus YMDD mutants is prognostic of viral DNA breakthrough. Gastroenterology. 2006 Apr;130(4):1144-52.

8. Yano M, Ohkoshi S, Suzuki K, Ito S, Wakabayashi H, Sugiyama M, Watanabe T, Maeda H, Hatakeyama SA, Hatano T, Kobayashi Y, Takei S, Kohjiro H, Tsuboi Y, Takahashi T, Ishikawa T, Kamimura T, Ichida T, Aoyagi Y. Absence of pretreatment markers that predict the emergence of YMDD mutants during lamivudine treatment--the results of a prospective multi-center study. Hepatogastroenterology. 2006 Jan-Feb;53(67):124-7.

9. Li D, Gu HX, Zhang SY, Zhong ZH, Zhuang M, Hattori T. YMDD mutations and genotypes of hepatitis $B$ virus in northern China. Jpn J Infect Dis. 2006 Feb;59(1):42-5. 10. Huang ZM, Huang QW, Qin YQ, Huang CH, Qin HJ, Zhou YN, Xu X, Lu CL. Clinical characteristics and distribution of hepatitis B virus genotypes in Guangxi Zhuang population. World J Gastroenterol. 2005 Nov 7;11(41):6525-9.

11. Economou M, Manolakopoulos S, Trikalinos TA, Filis S, Bethanis S, Tzourmakliotis D, Avgerinos A, Raptis S, Tsianos EV. Interferon-alpha plus lamivudine vs lamivudine reduces breakthroughs, but does not affect sustained response in HBeAg negative chronic hepatitis B. World J Gastroenterol. 2005 Oct 7;11(37):5882-7.

12. Horgan M, Brannigan E, Crowley B, Levis J, Fanning LJ. Hepatitis B genotype and YMDD profiles in an untreated Irish population. J Clin Virol. 2006 Feb;35(2):203-4.

13. Ni YH, Huang FC, Wu TC, Kong MS, Jeng YM, Chen PJ, Tsuei DJ, Chen HL, Hsu HY, Chang MH. Lamivudine treatment in maternally transmitted chronic hepatitis $B$ virus infection patients. Pediatr Int. 2005 Aug;47(4):372-7.

15. Moskovitz DN, Osiowy C, Giles E, Tomlinson G, Heathcote EJ. Response to long-term lamivudine treatment (up to 5 years) in patients with severe chronic hepatitis $B$, role of genotype and drug resistance. J Viral Hepat. 2005 Jul;12(4):398-404.

16. Pai SB, Bozdayi AM, Pai RB, Beker T, Sarioglu M, Turkyilmaz AR, Grier J, Yurdaydin C, Schinazi RF. Emergence of a novel mutation in the FLLA region of hepatitis $B$ virus during lamivudine therapy. Antimicrob Agents Chemother. 2005 Jul;49(7):2618-24.

17. Li MW, Hou W, Wo JE, Liu KZ. Character of HBV (hepatitis B virus) polymerase gene rtM204V/I and rtL180M mutation in patients with lamivudine resistance. J Zhejiang Univ Sci B. 2005 Jul;6(7):664-7. 18. Lee SY, Choi MS, Lee D, Lee JH, Koh KC, Paik SW, Yoo BC. Overlapping gene mutations of hepatitis $B$ virus in a chronic hepatitis $B$ patient with hepatitis $B$ surface antigen loss during lamivudine therapy. J Korean Med Sci. 2005 Jun;20(3):433-7.

19. Di Marco V, Di Stefano R, Ferraro D, Almasio PL, Bonura C, Giglio M, Parisi P, Cappello M, Alaimo G, Craxi A. HBV-DNA suppression and disease course in HBV cirrhosis patients on long-term lamivudine therapy. Antivir Ther. 2005;10(3):431-9.

20. Joh JW, Lee HH, Park JW, Lee DH, Yoo BC, Lee KW, Kim SJ. Genotypic resistance of hepatitis B virus to lamivudine in renal transplant recipients. Transplant Proc. 2005 Mar;37(2):1235-7. 
21. Marzano A, Lampertico P, Mazzaferro V, Carenzi S, Vigano M, Romito R, Pulvirenti A, Franchello A, Colombo M, Salizzoni M, Rizzetto M. Prophylaxis of hepatitis B virus recurrence after liver transplantation in carriers of lamivudine-resistant mutants. Liver Transpl. 2005 May;11(5):532-8. 22. Akuta N, Suzuki F, Kobayashi M, Matsuda M, Sato J, Suzuki Y, Sezaki H, Hosaka T, Someya T, Kobayashi M, Saitoh S, Arase Y, Ikeda K, Kumada H. Virological and biochemical relapse after discontinuation of lamivudine monotherapy for chronic hepatitis $B$ in Japan: comparison with breakthrough hepatitis during long-term treatment. Intervirology. 2005 Mar-Jun;48(2-3):174-82. 23. Akuta N, Suzuki F, Suzuki Y, Sezaki H, Hosaka T, Someya T, Kobayashi M, Saitoh S, Arase Y, Ikeda $\mathrm{K}$, Kobayashi M, Kumada $\mathrm{H}$. Favorable efficacy of long-term lamivudine therapy in patients with chronic hepatitis B: an 8-year follow-up study. J Med Virol. 2005 Apr;75(4):491-8.

24. Huang ZM, Huang QW, Qin YQ, He YZ, Qin HJ, Zhou YN, Xu X, Huang MJ. YMDD mutations in patients with chronic hepatitis B untreated with antiviral medicines. World J Gastroenterol. 2005 Feb 14;11(6):867-70.

25. Sun J, Wang Z, Ma S, Zeng G, Zhou Z, Luo K, Hou J. Clinical and virological characteristics of lamivudine resistance in chronic hepatitis B patients: a single center experience. J Med Virol. 2005 Mar;75(3):391-8.

26. Chaudhuri V, Tayal R, Nayak B, Acharya SK, Panda SK. Occult hepatitis B virus infection in chronic liver disease: full-length genome and analysis of mutant surface promoter. Gastroenterology. 2004 Nov;127(5):1356-71.

27. Yuen MF, Yuan HJ, Sablon E, Wong DK, Chan AO, Wong BC, Lai CL. Long-term follow-up study of Chinese patients with YMDD mutations: significance of hepatitis $B$ virus genotypes and characteristics of biochemical flares. J Clin Microbiol. 2004 Sep;42(9):3932-6.

28. Tacke F, Gehrke C, Luedde T, Heim A, Manns MP, Trautwein C. Basal core promoter and precore mutations in the hepatitis $B$ virus genome enhance replication efficacy of Lamivudine-resistant mutants. $J$ Virol. 2004 Aug;78(16):8524-35.

29. Jardi R, Rodriguez-Frias F, Buti M, Schaper M, Valdes A, Martinez M, Esteban R, Guardia J. Usefulness of dried blood samples for quantification and molecular characterization of HBV-DNA. Hepatology. 2004 Jul;40(1):133-9.

30. Chan TM, Tse KC, Tang CS, Lai KN, Ho SK. Prospective study on lamivudine-resistant hepatitis B in renal allograft recipients. Am J Transplant. $2004 \mathrm{Jul} ; 4(7): 1103-9$.

31. Hong SP, Kim NK, Hwang SG, Chung HJ, Kim S, Han JH, Kim HT, Rim KS, Kang MS, Yoo W, Kim SO. Detection of hepatitis $B$ virus YMDD variants using mass spectrometric analysis of oligonucleotide fragments. J Hepatol. 2004 May;40(5):837-44.

32. Huy TT, Abe K. Molecular epidemiology of hepatitis B and C virus infections in Asia. Pediatr Int. 2004 Apr;46(2):223-30.

33. Tsubota A, Arase Y, Suzuki F, Kobayashi M, Matsuda M, Sato J, Suzuki Y, Akuta N, Sezaki H, Hosaka T, Someya T, Kobayashi M, Saitoh S, Ikeda K, Kumada H. Severe acute exacerbation of liver disease may reduce or delay emergence of YMDD motif mutants in long-term lamivudine therapy for hepatitis B e antigen-positive chronic hepatitis B. J Med Virol. 2004 May;73(1):7-12.

34. Yuen MF, Wong DK, Sablon E, Yuan HJ, Sum SM, Hui CK, Chan AO, Wang BC, Lai CL. Hepatitis B virus genotypes $B$ and $C$ do not affect the antiviral response to lamivudine. Antivir Ther. 2003 Dec;8(6):531-4. 35. Yuen MF, Tanaka Y, Lai CL. Hepatitis B genotypes in chronic hepatitis B and lamivudine therapy. Intervirology. 2003;46(6):373-6.

36. Chien RN, Liaw YF. Short-term lamivudine therapy in patients with chronic hepatitis B. Intervirology. 2003;46(6):362-6.

37. Rodriguez-Novoa S, Gomez-Tato A, Aguilera-Guirao A, Castroagudin J, Gonzalez-Quintela A, Garcia-Riestra C, Regueiro BJ. Hepatitis B virus genotyping based on cluster analysis of the region involved in lamivudine resistance. J Virol Methods. 2004 Jan;115(1):9-17.

38. Zhou DY, Lin LY, Wang H, Huang JS. The relationship between HBV lamivudine resistance and HBV genotypes or basic core promoter mutations. Hepatobiliary Pancreat Dis Int. 2003 Feb;2(1):85-9. 39. Yuen MF, Kato T, Mizokami M, Chan AO, Yuen JC, Yuan HJ, Wong DK, Sum SM, Ng IO, Fan ST, Lai CL. Clinical outcome and virologic profiles of severe hepatitis $B$ exacerbation due to YMDD mutations. J Hepatol. 2003 Nov;39(5):850-5.

40. Bai YJ, Zhao JR, Lv GT, Zhang WH, Wang Y, Yan XJ. Rapid and high throughput detection of HBV YMDD mutants with fluorescence polarization. World J Gastroenterol. 2003 Oct;9(10):2344-7. 
41. Akuta N, Suzuki F, Kobayashi M, Matsuda M, Sato J, Takagi K, Tsubota A, Suzuki Y, Hosaka T, Someya T, Kobayashi M, Saitoh S, Arase Y, Ikeda K, Kumada H. Virological and biochemical relapse according to YMDD motif mutant type during long-term lamivudine monotherapy. J Med Virol. 2003 Dec;71(4):504-10.

42. Kim KH, Lee KH, Chang HY, Ahn SH, Tong S, Yoon YJ, Seong BL, Kim SI, Han KH. Evolution of hepatitis $B$ virus sequence from a liver transplant recipient with rapid breakthrough despite hepatitis $B$ immune globulin prophylaxis and lamivudine therapy. J Med Virol. 2003 Nov;71(3):367-75.

43. Suzuki F, Tsubota A, Arase Y, Suzuki Y, Akuta N, Hosaka T, Someya T, Kobayashi M, Saitoh S, Ikeda K, Kobayashi M, Matsuda M, Satoh J, Takagi K, Kumada H. Efficacy of lamivudine therapy and factors associated with emergence of resistance in chronic hepatitis B virus infection in Japan. Intervirology. 2003;46(3):182-9.

44. Bozdayi AM, Uzunalimoglu O, Turkyilmaz AR, Aslan N, Sezgin O, Sahin T, Bozdayi G, Cinar K, Pai SB, Pai R, Bozkaya H, Karayalcin S, Yurdaydin C, Schinazi RF. YSDD: a novel mutation in HBV DNA polymerase confers clinical resistance to lamivudine. J Viral Hepat. 2003 Jul;10(4):256-65.

45. Akuta N, Suzuki F, Kobayashi M, Tsubota A, Suzuki Y, Hosaka T, Someya T, Kobayashi M, Saitoh $\mathrm{S}$, Arase $\mathrm{Y}$, Ikeda $\mathrm{K}$, Kumada $\mathrm{H}$. The influence of hepatitis $\mathrm{B}$ virus genotype on the development of lamivudine resistance during long-term treatment. J Hepatol. 2003 Mar;38(3):315-21.

46. Ben-Ari Z, Daudi N, Klein A, Sulkes J, Papo O, Mor E, Samra Z, Gadba R, Shouval D, Tur-Kaspa R. Genotypic and phenotypic resistance: longitudinal and sequential analysis of hepatitis $B$ virus polymerase mutations in patients with lamivudine resistance after liver transplantation. Am J Gastroenterol. 2003 Jan;98(1):151-9. 47. Akuta N, Tsubota A, Suzuki F, Suzuki Y, Hosaka T, Someya T, Kobayashi M, Saitoh S, Arase Y, Ikeda $\mathrm{K}$, Kumada $\mathrm{H}$. Long-term prognosis by lamivudine monotherapy for severe acute exacerbation in chronic hepatitis B infection: emergence of YMDD motif mutant and risk of breakthrough hepatitis -- an open-cohort study. J Hepatol. 2003 Jan;38(1):91-7.

48. Nguyen MH, Wright TL. Therapeutic advances in the management of hepatitis B and hepatitis $\mathrm{C}$. Curr Opin Infect Dis. 2001 Oct;14(5):593-601.

49. Bruno R, Sacchi P, Malfitano A, Filice G. YMDD-mutant HBV strain as a cause of liver failure in an HIV-infected patient. Gastroenterology. 2001 Oct;121(4):1027-8.

50. Papatheodoridis GV, Hadziyannis SJ. Diagnosis and management of pre-core mutant chronic hepatitis B. J Viral Hepat. 2001 Sep;8(5):311-21.

51. Gutfreund KS, Williams M, George R, Bain VG, Ma MM, Yoshida EM, Villeneuve JP, Fischer KP, Tyrrel DL. Genotypic succession of mutations of the hepatitis B virus polymerase associated with lamivudine resistance. J Hepatol. 2000 Sep;33(3):469-75.

52. Gunther S, von Breunig F, Santantonio T, Jung MC, Gaeta GB, Fischer L, Sterneck M, Will H. Absence of mutations in the YMDD motif/B region of the hepatitis $B$ virus polymerase in famciclovir therapy failure. J Hepatol. 1999 May;30(5):749-54.

53. Zöllner B et al, Viral features of lamivudine resistant hepatitis B genotypes A and D

54. Heo J, Cho M et al J Korean Med Sci 2004,19:541-6

55. Schaefer S. et al, Hepatitis B genotypes in Europe, Hepatol Res. 2007 Jul;37(s1):S20-6

56. Amini-Bavil-Olyaee S. et al, Hepatitis B virus (HBV) genotype and YMDD motif mutation profile among patients infected with HBV and untreated with lamivudine, Int J Infect Dis. 2008 Jan;12(1):83-7 57. Franca $\mathrm{PH}$ et al, The emergence of YMDD mutants precedes biochemical flare by 19 weeks in lamivudine-treated chronic hepatitis B patients: an opportunity for therapy reevaluation, Braz J Med Biol Res. 2007 Dec;40(12):1605-14

58. X. P. Pan, L. J. Li, W. B. Du, M. W. Li, H. C. Cao and J. F. Sheng, Differences of YMDD mutational patterns, precore/core promoter mutations, serum HBV DNA levels in lamivudine-resistant hepatitis $B$ genotypes B and C, J Viral Hepat. 2007 Nov;14(11):767-74

59. Gwak GY, The incidence and clinical outcome of YMDD mutants in hepatitis B surface antigenpositive renal allograft recipients after prolonged lamivudine therapy, Transplant Proc. 2007 Dec;39(10):3121-6

61. Bielawski KP, Determination of lamivudine-resistant variants of hepatitis B virus by denaturing gradient gel electrophoresis: a novel approach to monitoring drug resistance, Med Sci Monit. 2008 May;14(5):CR281-285.Click here to read

62. Xu WZ, Construction and expression of eukaryotic plasmids containing lamivudine-resistant or wildtype strains of Hepatitis B Virus genotype C, World J Gastroenterol. 2008 Jun 21;14(23):3733-8

63. Yuki $\mathrm{N}$, Adding interferon to lamivudine enhances the early virologic response and reversion of the precore mutation in difficult-to-treat HBV infection, J Gastroenterol. 2008;43(6):457-63 
64. Gora-Gepka H. et al, HBV gene variants and polymerse gene mutations in children with chronic hepatitis B in the course of the antiviral therapy, Med Wieku Rozwoj. 2007 Oct-Dec;11(4):367-71 65. Whang WP, RtL164V, a mutation possibly associated with lamivudine resistant HBV, Zhonghua Gan Zang Bing Za Zhi. 2008 Jul;16(7):490-3

66. Shih $\mathrm{YH}$, Hepatitis $\mathrm{B}$ virus quantification and detection of YMDD mutants in a single reaction by realtime PCR and annealing curve analysis, Antivir Ther. 2008;13(4):469-80

67. Woo HY et al, Evaluation of dual priming oligonucleotide-based multiplex PCR for detection of HBV YMDD mutants, Antivir Ther. 2008;13(4):469-80

68. Kim do Y, Clinical course of virologic breakthrough after emergence of YMDD mutations in $\mathrm{HBeAg}$ positive chronic hepatitis B, Intervirology. 2008;51(4):293-8

69. Masaadeh HA, Hepatitis B virus genotypes and lamivudine resistance mutations in Jordan, World $\mathrm{J}$ Gastroenterol. 2008 Dec 21;14(47):7231-4

70. Salabe $S$ et al., Frequent detection of hepatitis B virus variants associated with lamivudine resistance in treated South African patients infected chronically with different HBV genotype, J Med Virol. 2009 Jun;81(6):996-1001

71. lacomi F et al, Effect of HIV Co-Infection on Mutation Patterns of HBV in Patients With LamivudineResistant Chronic Hepatitis B, J Med Virol. 2009 Jul;81(7):1151-6.

72. Bottechia et al Hepatitis $B$ virus genotypes and resistance mutations in patients under long term lamivudine therapy: characterization of genotype G in Brazil, BMC Microbiol. 2008 Jan 22;8:11. 